\title{
Teacher Interventions to Induce Students' Awareness in Controlling their Intuition
}

\section{Intervenções do Professor para Induzir a Consciência do Aluno no Controle de sua Intuição}

\author{
Puguh Darmawan* \\ ORCID 0000-0001-5870-1289 \\ Purwanto** \\ ORCID 0000-0003-0974-4068 \\ I Nengah Parta ${ }^{* * *}$ \\ ORCID 0000-0003-4255-9323 \\ Susiswo $^{* * * *}$ \\ ORCID 0000-0001-6461-6283
}

\begin{abstract}
This study aimed to describe teacher interventions in students' problem-solving. The subjects were three upperclass students at an elementary school in Indonesia who used system 2 when solving problems. This study used a qualitative case study approach. Data were obtained from students' written answers and audio-visual recordings of teacher interventions to students. The results showed that the subjects needed teacher interventions to induce their awareness when involving system 2. Each subject needed intervention different stages. Subject 1 required intervention stage 3 , subject 2 required intervention stage 2 , and subject 3 only required intervention at stage 1 . From the research results, it was known that the active moment of system 2 in all three subjects was the same, that is after the core problem was known. The core of the problem was ascertained after a doubtful feeling arose on the truth of the resulting answers. This feeling arose because the teacher intervened in the form of questions conducted dialogically.
\end{abstract}

Keywords: Intervention. Intuition. Dual-process Theory. Problem-solving.

\section{Resumo}

Este estudo teve como objetivo descrever as intervenções dos professores na solução de problemas dos alunos. Os sujeitos eram três alunos da classe alta, de uma escola primária na Indonésia, que utilizavam o sistema 2 para resolver problemas. Trata-se de um estudo de caso com abordagem qualitativa. Os dados foram obtidos a partir

\footnotetext{
* Doctor of Mathematics Education at Universitas Negeri Malang (UM). Lecturer of Mathematics Education at Universitas PGRI Banyuwangi (UNIBA), Banyuwangi, Jawa Timur, Indonesia. E-mail: puguhdarmawan212@gmail.com.

** Doctor of Philosophy of Mathematics at Curtin University of Technology (CUT). Profesor of Mathematics at Universitas Negeri Malang (UM), Malang, Jawa Timur, Indonesia. E-mail: purwanto.fmipa@um.ac.id.

*** Doctor of Mathematics Education at Universitas Negeri Surabaya (UNESA). Lecturer of Mathematics Education at Universitas Negeri Malang (UM), Malang, Jawa Timur, Indonesia. E-mail: nengah.parta.fmipa@um.ac.id.

***** Doctor of Mathematics Education at Universitas Negeri Malang (UM). Lecturer of Mathematics Education at Universitas Negeri Malang (UM), Malang, Jawa Timur, Indonesia. E-mail: susiswo.fmipa@um.ac.id.
} 
das respostas escritas dos alunos, além das videogravações das intervenções dos professores. Os resultados mostraram que os sujeitos precisaram de intervenções do professor para induzir sua consciência quanto à assimilação do sistema 2. Cada sujeito precisou de uma intervenção, nos diferentes estágios. O sujeito 1 exigiu intervenção no estágio 3; o sujeito 2 exigiu intervenção no estágio 2; o sujeito 3 exigiu apenas no estágio 1 . A partir dos resultados da pesquisa, definiu-se que o momento ativo do sistema 2, nos três sujeitos, foi o mesmo, isso é, depois que tomaram conhecimento do problema principal. O cerne do problema foi apurado após surgir um sentimento duvidoso sobre a veracidade dos resultados. Esse sentimento surgiu porque o professor interveio na forma de perguntas, conduzidas dialogicamente.

Palavras-chave: Intervenção. Intuição. Teoria de processos duplos. Resolução de problemas.

\section{Introduction}

Problem-solving is an essential topic in Mathematics instruction (BALTACI; YILDIZ; GUVEN, 2014; CUNHA; LAUDARES, 2017; GUVEN: OZUM, 2013; JACINTO; CARREIRA, 2017; SPINILLO et al, 2017; CĂPRIOARĂ, 2015), taught since the elementary school level (AMARAL; CARREIRA, 2017; SOUSA; MENDES, 2017). Problem-solving learning is pivotal to improve students' reasoning ability in solving everyday problems, being unseparated from Mathematics itself (TAMBYCHIK; SUBAHAN; MEERAH, 2010). However, students' reasoning is frequently lacking in solving the problem at hand. Inadequate reasoning may cause difficulties and failures in problem-solving (BABAI; SHALEV; STAVY, 2015; MULLIS et al., 2012; OECD, 2018).

Inadequate reasoning generally occurs because students do not have conceptual and procedural knowledge (BORODIN, 2016; DARMAWAN et al., 2020; LERON; HAZZAN, 2009). However, even when students have conceptual and procedural knowledge, difficulties can still occur. When students do not know the core of the problem, their attention is not directed to information, giving solutions to the problem. Directing attention to information that supports solutions to problems is the most necessary cognitive ability that students can have. This ability is the initial step in students' success because it underpins the next steps.

Students' attention focuses on specific information due to one of the following two conditions. For example, there is salient information which invites students' attention unconciously (BABAI; SHALEV; STAVY, 2015; LEM, 2015) and students intentionally direct attention to relevant information based on learning experience and goals (LAMY; LEBER; EGETH, 2004; LLERAS; VON MÜHLENEN, 2004; ZINK et al., 2004). The first condition often causes students' difficulties in solving problems because of a lack of consideration in generating a response. The mental activity, called system 1 , generates a response in the first condition.

According to the dual-process theory, there are two mental activities in reasoning, such 
as system 1 and system 2 . The salient information from the problem will be the signal that generates system 1 (EVANS, 2018). Moreover, students will automatically match it with the mental structure that is easier to retrieve from long-term memory without considering its relevance (MARTIN; SLOMAN, 2013; BELLINI-LEITE, 2018; DURNING et al., 2015; HANDLEY; TRIPPAS, 2015).

System 1 processes are fast, automatic, subjective-empirical, and unconcious (DARMAWAN et al., 2020; KAHNEMAN, 2003). System 1 refers to the terminology that was previously widely used, namely intuition, while system 2 refers to analytical thinking (BORODIN, 2016; DE NEYS, 2018; IMBIR, 2016). System 1 can cause difficulties that even students fail in problem-solving if system 2 is not actively involved in giving control (BAGO; DE NEYS, 2017; LERON; HAZZAN, 2009). When system 1 produces a response that does not lead to a solution, it will affect the students' reasoning (BABAI; SHALEV; STAVY, 2015). The involvement of system 2 is quite significant because the process has some characteristics, concious, accuracy-empirical, and can be controlled (DARMAWAN et al., 2020). Therefore, it has the potential to refer to applicable and flexible rules (KAHNEMAN, 2003).

The previous studies done by other researchers have revealed the difficulties and failures of students in solving problems from various mathematical domains, such as arithmetic, geometry, and probability, due to the non-involvement of system 2 in controlling the response of system 1 (BABAI; SHALEV; STAVY, 2015; DE NEYS, 2015; DOOREN et al., 2003; FISCHBEIN, 1999; LEM, 2015; STAVY; TIROSH, 2000). The geometry domain example, in the study of Stavy and Tirosh (2000), is students comparinge larger perimeter between the following two polygons.

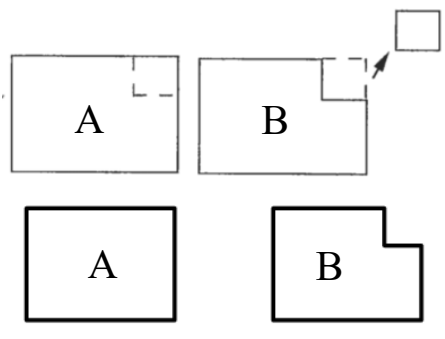

Figure 1 - Polygon

Source: Stavy and Tirosh (2000, p. 17)

Polygon A is a rectangle, while polygon $\mathrm{B}$ is obtained from polygon $\mathrm{A}$ in which one corner is changed. The area of polygon A is larger than the area of polygon B, but the perimeter remains the same. In fact, 70\% of grade 9 students in Stavy and Tirosh's (2000) study stated that polygon A has a larger perimeter because its area is larger than polygon $\mathrm{B}$. The area of the polygon is salient information and generates system 1 . The students intuitively believe that if 
the area of polygon A is bigger, the perimeter will also be larger than polygons, which size is smaller.

Similar problems caused by system 1 response also occurred in problem-solving on probability. Students were given the following problem.

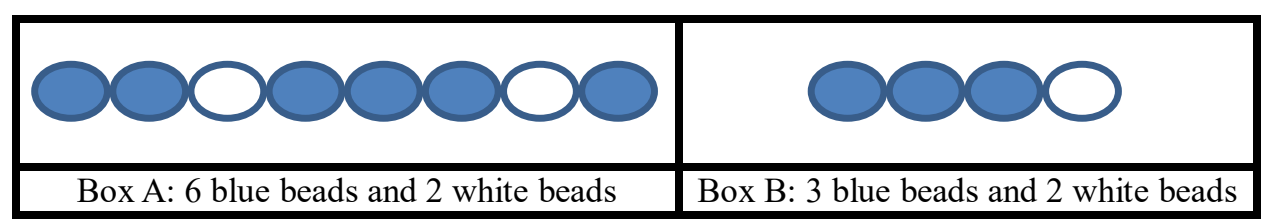

Figure $2-$ Box A and Box B

Source: Green (1983)

Students were asked to choose box A or box B which has a greater probability of taking white beads. Green data (1983) showed that more students chose box A than box B. In fact, the chance of getting white beads from box A is one eighth. While the chance of getting white beads from box $\mathrm{B}$ is bigger than one eighth, which is one third. The number of beads in box A made students system 1 active. Box A was automatically selected because of the visual impression generated by the number of beads in box A. The number of beads in box A is bigger than the beads in box B. The researcher also found similar indications in the students' answers related to the problems given during the preliminary research below.

Price Problem: The price of one pencil and one eraser is IDR 1,500. The price of one pencil is IDR 1,000 more expensive than the price of one eraser. How much is the price of one eraser?

The above problem was given by the researcher to 60 upper-class students at an elementary school in Indonesia. A total of 58 students answered IDR 500 and a student answered IDR 1,000. Here is one of the students' answers.

\begin{tabular}{|l|}
\hline \\
1 Harga satu pensil dan 50 tu penghopus adaloh RP 1500 . Warga \\
Satu pensil odalah Rp 1000 lebih mohal dari harga satu perghapus \\
Berapa harga I penghapus Ttup \\
Rp 500
\end{tabular}

Figure 3 - Student's answer

Source: Researcher' data (2018)

The data reveal that more than $90 \%$ of students made mistakes in answering. The mistake is largely due to the salient information of 1,000 and 1,500, which encourages students to respond quickly and automatically, by subtracting 1,000 from 1,500. A fast and automatic process is a characteristic of system 1 . In this case, the conclusion to subtract 1,000 from 1,500 is not preceded by premises that corroborate this conclusion.

Stavy and Tyrosh's (2000) research data and Green's (1983) research data, preliminary 
study data of this research were resulted from the same conditions. The same condition covered the research subject owned sufficient conceptual and procedural knowledge to solve the given problem. However, the research subject failed to solve the problem that should have been solved because system 1 was active without involving system 2 .

Several studies have revealed effective ways to control the response of system 1 by generating system 2, giving intervention in the forms of appeals or warnings. Babai, Shalev and Stavy (2015) and Dewolf et al. (2014) give a warning before students take the test. Babai, Shalev and Stavy (2015) urge students to be vigilant, because the test questions contain distractors. Dewolf et al. (2014) remind students using the illustration of a picture. The researcher did the same thing during preliminary research by giving classical verbal appeals before students solve the problems. The researcher urged students to check the truth of the answer before submitting it by determining the price of one eraser and one pencil while calculating the difference in price, whether it matches the information on the given problem.

The researcher's appeal was more explicit than Babai, Shalev and Stavy (2015) and Dewolf et al. (2014), but over $90 \%$ of the students still made mistakes in their answer andtended to be intuitive. For this reason, according to the researcher, there is a need for continuous teacher interventions to raise students' awareness in involving system 2, so that they can focus their thinking on the steps towards a solution. This opinion was based on empirical facts when one of the students, was given further interventions after the previous appeal that was given classically at the beginning. The intervention was in the form of questions. The researcher's questions stimulated the student to rethink, and therefore system 2 had the opportunity to be actively involved. The following is the excerpt of the researcher's dialogue with the student.

Researcher: Are you sure of your answer?

Student : Yes, sir.

Researcher: Really?

Student : Wait a minute, sir, hmm it seems right. Uh let me check it first.

(Dialogue between researcher and Student, 2018)

Based on the dialogue above, the students were triggered to evaluate the answer after the researcher asked their belief in the truth of the answers given. The researcher's questions were proven to be a trigger for the students' awareness to reconsider the answers that were generated. Based on the indications above, it is necessary to conduct a study on teacher interventions that can induce students' awareness to involve system 2 as a response controller of system 1 . 


\section{Research Objectives}

Based on the introduction arguments on the importance of awareness to involve system 2 in problem solving, this study aimed to describe teacher interventions on students which can induce awareness, so that system 2 is active in solving problems.

\section{Research Design and Participants}

This study used a qualitative research approach with a case study design. The case studied in this study was teacher interventions that induce students' awareness to involve system 2 as a controlling response of system 1, which is fast and automatic as a result of the salient information. In this study, the researcher became a teacher. The participants of this study were 60 upper-class students at an elementary school (grade 4 and grade 5) in Indonesia. Those upper-class students at elementary school were chosen for two main reasons, namely, 1) problem-solving learning begins in elementary school (NCTM, 2000), and 2) the communication skills of upper-class students make it easier for researcher to explore students' thinking. Those 60 upper-class students at elementary schools consist of 35 fourth-graders and 25 fifth-graders from three different elementary schools in Indonesia.

In this study, the researcher proposed problems to the participants in each school at different times. Each student solved problems individually with a duration of 10-20 minutes. After completing the work, the students, one by one, were asked to submit their written answers and the researcher checked the answers while giving interventions to the students whose answers were incorrect. The incorrect answer indicates that the response is generated by system 1. Then, students who evaluated the answer after the researcher gave interventions were chosen as the prospective research subjects. The students who evaluated their answers were chosen because they were indicated to use system 2 (THOMPSON; JOHNSON, 2014). There are three types of responses after the students evaluated the answers to produce correct answers, namely guessing, making a list, and modeling. In this study, each type of response is represented by one student as the study subject.

\subsection{Instruments}

The problem in this study was developed from the problem of Kahneman (2003). It was chosen to be developed and used because, 1) it has a real-world context, 2) it is suitable within 
the material studied by elementary school students, and 3) it is tested on Kahneman's research participants and results in data that over $50 \%$ of participants do not involve system 2 to control the response system 1. In Kahneman's problem, it is known that the price of one baseball bat and one ball is 1 dollar and 10 cents, and the price of the bat is 1 dollar more expensive. Kahneman's problem asks the price of one ball. Then, the problem development is in the form of adjusting the problem context with the real situation in Indonesia. The parts that were adjusted included 1) baseball bat and the ball were adjusted to pencil and eraser, and 2) 1 dollar and 1 dollar 10 cents as the salient information (KAHNEMAN, 2003) were adjusted to IDR 1,000 and $I D R$ 1,500 The followings are the results of these adjustments.

Price Problem: The price of one pencil and one eraser is IDR 1,500. The price of one pencil is IDR 1,000 more expensive than the price of one eraser. How much is the price of one eraser?

The price problem above has been validated by two experts in Mathematics Education. Validation was carried out on two aspects. First, validation was carried out on the aspect of problem suitability with the research purpose. Second, validation was carried out on the problem suitability aspect with the skill of $4^{\text {th }}$ and $5^{\text {th }}$ graders. The price problem above was declared valid and was tested on 35 students in $4^{\text {th }}$ grade and 45 students in $5^{\text {th }}$ grade. The trial data were used to perfect the price problem instrument. This was done to ensure problem effectiveness in supporting the achievement of research objectives.

\subsection{Data collection and data analysis}

Data were generated from the subjects' written answers and audio-visual recordings of the researcher interventions in the form of questions on the subject. Interventions were carried out in a dialogical manner with an unlimited duration. The intervention duration is adjusted to the subject's condition. Data were, then, used to describe the variation of the intervention stage, which can raise the subject's awareness to involve system 2 in controlling system 1 response. The following is the description of each intervention stage.

\begin{tabular}{|c|c|c|c|}
\hline $\begin{array}{c}\text { Intervention } \\
\text { Stage }\end{array}$ & $\begin{array}{c}\text { Moments of } \\
\text { intervention }\end{array}$ & $\begin{array}{c}\text { The indicator of the need for } \\
\text { intervention }\end{array}$ & Question Form \\
\hline Stage 1 & $\begin{array}{c}\text { After subjects } \\
\text { submit their first } \\
\text { written answer }\end{array}$ & 1. The subject's answer is incorrect & $\begin{array}{c}\text { 1. Raising the subject's } \\
\text { awareness that the answer is } \\
\text { incorrect and the subject } \\
\text { evaluates it }\end{array}$ \\
Stage 2 & After intervention \\
stage 1 & $\begin{array}{c}\text { 1. The subject does not realize that } \\
\text { the answer is incorrect } \\
\text { belief in the truth of the } \\
\text { answer }\end{array}$ & $\begin{array}{c}\text { 1. Getting directly to problem } \\
\text { content }\end{array}$ \\
\hline
\end{tabular}




\begin{tabular}{|c|c|c|c|}
\hline $\begin{array}{c}\text { Intervention } \\
\text { Stage }\end{array}$ & $\begin{array}{c}\text { Moments of } \\
\text { intervention }\end{array}$ & $\begin{array}{c}\text { The indicator of the need for } \\
\text { intervention }\end{array}$ & Question Form \\
\hline & & $\begin{array}{c}\text { 2. The subject still believes that the } \\
\text { answer is correct after the researcher } \\
\text { repeats the same question in the } \\
\text { intervention stage } 1 \\
\text { 3. The subject thinks that it is } \\
\text { finished, which is indicated by } \\
\text { leaving the answer sheet to the } \\
\text { researcher }\end{array}$ & $\begin{array}{c}\text { 2. Raising the subject's } \\
\text { awareness that the answer is } \\
\text { incorrect and therefore the } \\
\text { subject evaluates it }\end{array}$ \\
\hline Stage 3 & After intervention & $\begin{array}{c}\text { 1. The subject realizes that the answer } \\
\text { is incorrect }\end{array}$ \\
& stage 2 & $\begin{array}{c}\text { 2. The subject does not know the } \\
\text { main problem, which is marked by a) } \\
\text { reading the text of the problem } \\
\text { repeatedly, and b) asking themselves }\end{array}$ & $\begin{array}{c}\text { 1. Getting directly to problem } \\
\text { content }\end{array}$ \\
2. Structuring the problem \\
3. Leading to a solution
\end{tabular}

Frame 1 - The description of the intervention stage

Source: Researcher' data (2018)

Based on Frame 1 above, the results of the teachers' intervention on the subject were presented and analyzed at each intervention stage. The things that occurred at each intervention stage were described in accordance with the subjects' written answers and the results of the audio-visual recording. Then, the results of data analysis from each subject were compared to be formulated. Based on this, we knew the characteristics of effective teachers' intervention for students to induce students' awareness in involving system 2.

\section{Results}

This section describes the researcher intervention on the subject during problem-solving to produce a solution or correct answer. The issues discussed in this section include Subject 1's case (intervention up to stage 3), Subject 2's case (intervention up to stage 2), and Subject 3's case (stage 1 intervention).

\subsection{Interventions stage 1, stage 2, and stage 3: The case of Subject 1 (Guessing)}

The following is Subject 1's initial answer to the problem the researcher gave.

$$
\begin{aligned}
& 1.500 \\
& \frac{1.000}{500}-
\end{aligned}=500
$$

Figure 4 - Subject 1's initial answer

Source: Researcher' data (2018)

Subject 1 answered 500, which was obtained from 1,500 - 1,000 = 500, quickly and verbally. 1,500 and 1,000 are salient information that causes a "saliency effect", so naturally, 
Subject 1 was compelled to immediately provide the answer that was most easily obtained by operating the information. The answer came from an implicit/tacit process, so there was no detailed algorithm and clear reasons for the steps taken. This was in accordance with the characteristics of system 1 process formulated by Borodin (2016). Then, the researcher gave stage 1 intervention, and therefore Subject 1 realized that the answer was incorrect and evaluated it as follows.

Researcher: Are you sure of your answer?

Subject 1: Sure.

Researcher: Really? Is that correct?

Subject 1: Yes.

(Dialogue between researcher and Subject 1, 2018)

Subject 1 still believed her answer was correct after the researcher repeated the same question. According to Mihaela and Voica (2008), one thinks it is not necessary to test the truth of the answer empirically or formally because (s)he believes the answer is correct if the mental process that occurs is system 1 . Subject 1 did not realize that the answer was incorrect, and there was no indication that she would evaluate it. Subject 1 thought that it was finished, so she left her answer. For this reason, the researcher asked Subject 1 to stay at her place and moved to stage 2 intervention as follows.

Researcher: What is the total price?

Subject 1:IDR 1,500.

Researcher: If the total is 1,500, how much is the price of one pencil and the price of one eraser?

Subject 1: 1,000 and 500

Researcher: So, it means that the price of one pencil is more expensive; how much is the price of one eraser?

Subject 1: 500

Researcher: From the question, how much is the difference in priceof one pencil and one eraser? Subject 1: Hmm ... 1,000

Researcher: How much? What is your answer?

Subject 1: 500, yeah yeah.

(Dialogue between researcher and Subject 1, 2018)

The question of the difference between the price of one pencil and one eraser made Subject 1 realized that the answer was incorrect. A moment later, Subject 1 resubmitted an answer as follows.

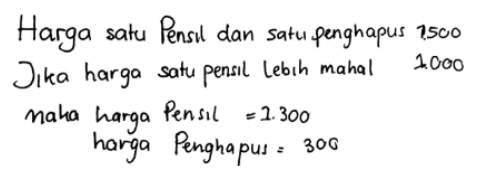

Translation: The price of one pencil and one eraser is IDR 1,500. If the price of one pencil is IDR 1,000 more expensive, then, the price of one pencil is Rp.1300, and the price of one eraser is Rp. 300 
The answer above does not indicate that it was generated by system 2 because it does not represent an explicit algorithm, it does not represent a detailed step of sequences with clear reasons to reach the conclusion that the price of one eraser is 300 . Subject 1 did not realize that the sum of 1,300 and 300 contradicted the information given, even though the difference is correct, that is 1,000 . The answer above is also not generated by system 1 . If the response is generated by system 1, the truth will be believed even though there is no formal explanation (FISCHBEIN; SCHNARCH, 1999; MIHAELA; VOICA, 2008; PARSONS, 2008). The answer above resulted from guessing. When the researcher asked how Subject 1 produced the answer, she could not explain and did not believe the truth. The difference between guessing and system 1 is the true belief that accompanies the emergence of the response (FU; DIENES; FU, 2010). Here is the dialogue between researcher and Subject 1 .

\section{Researcher: How did you get 1,300 and 300? \\ Subject 1: Hmm I don't know \\ Researcher: Are you sure that this is correct? \\ Subject 1: Hmm ... I don't know \\ (Dialogue between researcher and Subject 1,2018)}

After the dialogue above, Subject 1 read the problem repeatedly, asked her-self, and did not write anything. It indicates that she found it difficult structuring the problem and did not know the core of the problem. For this reason, the researcher gave stage 3 intervention as follows.

Researcher: If the price of one pencil is 1,300 and the price of one eraser is 300, how much is it altogether?

Subject 1: 1,600.

Researcher: In the question, how much is the total?

Subject 1: Yeah yeah

(Dialogue between researcher and Subject 1, 2018)

After 20 minutes of the above dialogue, Subject1 offered the correct answer as follows.

$$
\begin{array}{ll}
\text { harga } 1 \text { pensil }=1250 \\
\text { harga } 1 \text { penghapus }=250
\end{array}
$$

Translation: The price of one pencil is $I D R$ 1,250 and the price of one eraser is IDR 250

Figure 6 - Subject 1's second guessing Source: Researcher' data (2018)

Then the researcher asked about how Subject 1 produced the answer.

Researcher: How did you get the answer?

Subject 1: Guessing, sir.

Researcher: What do you mean?

Subject 1: I chose numbers randomly, and then calculated the difference and the total whether it is correct or not.

(Dialogue between researcher and Subject 1, 2018) 
Subject 1 produced the correct answer also by guessing as mentioned in her statement that is "I chose numbers randomly, and then calculated the difference and the total whether it is correct or not". System 2 was involved after stage 3 intervention when Subject 1 calculated the difference and total price. The counting process occurs in working memory with a full effort which is the characteristic of system 2 (BORODIN, 2016; EVANS, 2012; MARTIN; SLOMAN, 2013). System 2 was also involved in giving the approval to choose the guessing as a response represented as an answer. The following scheme shows the sequence of Subject 1's mental process when solving problems with the researcher interventions that occur in six phases.

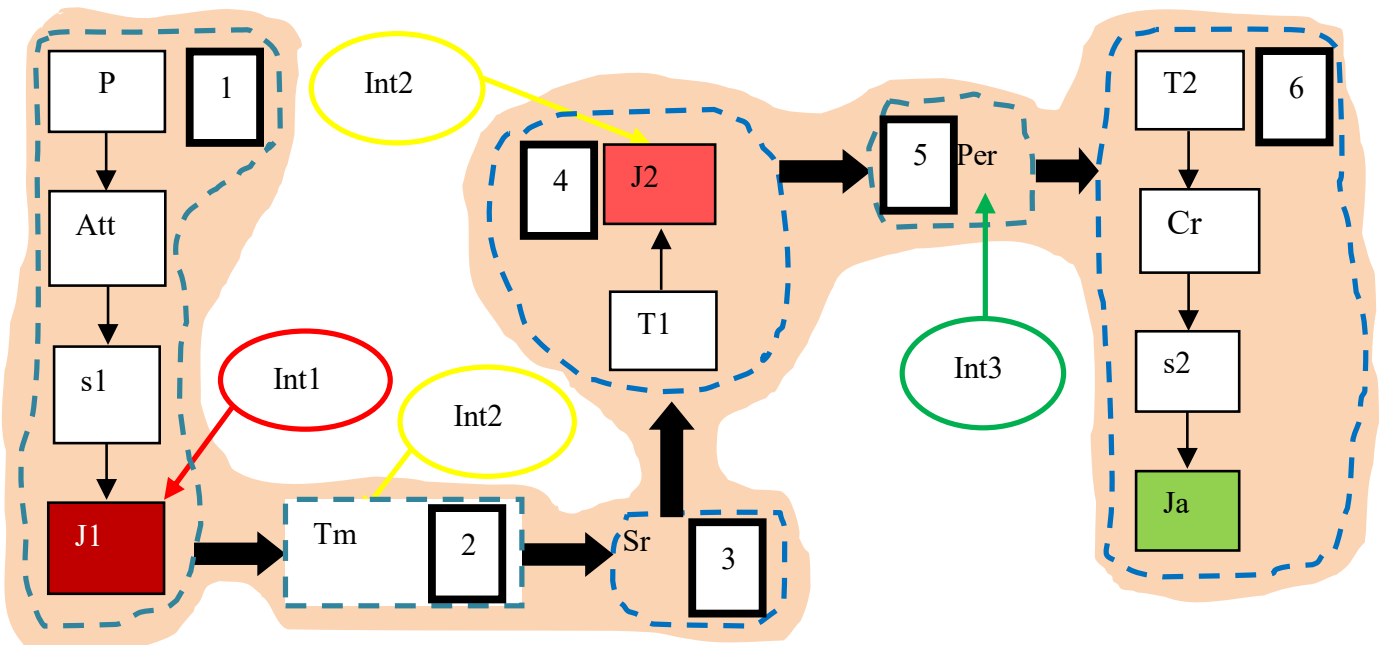

Figure 7 - Subject 1's mental scheme Source: Researcher' data (2018)

The following is the description of the scheme above.

\begin{tabular}{|c|c|}
\hline Code & Meaning \\
\hline $\mathrm{P}$ & Price problem \\
\hline $\mathrm{Att}$ & Encouraged to pay attention to IDR 1,000 and IDR 1,500 \\
\hline $\mathrm{s} 1$ & System 1 is active \\
\hline $\mathrm{J} 1$ & Stage 1 intervention \\
\hline $\mathrm{Int} 1$ & Stage 2 intervention \\
\hline $\mathrm{Tm}$ & not aware that the answer is incorrect and not evaluating the answer \\
\hline $\mathrm{Int} 2$ & Guessing for the first time \\
\hline $\mathrm{Sr}$ & the second incorrect answer is 300 \\
\hline $\mathrm{T} 1$ & Confused \\
\hline $\mathrm{J} 2$ & Guessing for the second time \\
\hline $\mathrm{Per}$ & Prospective answer \\
\hline $\mathrm{T} 2$ & System 2 is active to evaluate prospective answers \\
\hline $\mathrm{Cr}$ & The correct answer is 250 \\
\hline $\mathrm{s} 2$ & $\mathrm{Ja}$
\end{tabular}

Frame 2 - The description of Subject 1's mental scheme

Source: Researcher' data (2018) 


\subsection{Intervention stage 1, stage 2: The case of Subject 2 (Making a list)}

Subject 2's initial answer to the question was IDR 500. He answered it quickly and verbally. Also, it was written without an algorithm. Subject 2 insisted that there was no other correct answer except IDR 500, which was revealed when the researcher gave stage 1 intervention as follows.

Researcher: Are you sure of your answer?

Subject 2: Sure, sir.

Researcher: Really? Is that right?

Subject 2: The only answer is 500 .

(Dialogue between researcher and Subject 2, 2018)

Subject 2 thought that he had finished, and left his answer after the dialogue above. Stage 1 intervention in making him realize that the answer was incorrect. The process of answer emergence that is fast, implicit, inflexible, non-algorithmic, and believed to be true is the characteristic of a system 1 process (BABAI; SHALEV; STAVY, 2015; BORODIN, 2016; MARTIN; SLOMAN, 2013). Inflexible in this case means that Subject 2 rejected other alternatives that might be true. The researcher, then, asked him to stay at his place and provided stage 2 intervention, hoping that he would realize that the answer was incorrect and evaluate it as in the dialog below.

Researcher: If your answer is 500, how much is the price difference for one pencil?

Subject 2: Hmm ... 500

Researcher: How much is the difference based on the question?

Subject 2: Oh yeah, how does it work, hmm ...

(Dialogue between researcher and Subject 2, 2018)

The question on the price difference of a pencil and an eraser triggered his awareness that the answer was not in accordance with the information provided. After 20 minutes of the dialogue above, Subject 2 gave the following answer.

\begin{tabular}{|cccc|}
\hline$T$ & $P$ & $B$ & $S$ \\
1500 & 1400 & 100 & 1300 \\
& 1300 & 200 & 1100 \\
1200 & 300 & 900 \\
1250 & 250 & 1000 \\
\hline
\end{tabular}

Figure 8 - Subject 2's making list strategy

Source: Researcher' data (2018)

Furthermore, Subject 2 explained the answer as follows.

Researcher: Try to explain how you produced the answer.

Subject 2: The total price is 1,500 then I made the possibility of a total price of 1,500 I started from 1,400 \& 100 but it was incorrect because the difference is 1,300. Based on the question, the difference is 1000. Then, I decrease the price step-by-step by making a list, 1,300 \& 200 the difference is 1,$100 ; 1200 \& 300$, the difference is 900 . Then, my final answer is I subtracted it 
ten-by-ten, and it gets to the pairs of $1,250 \& 250$, and the difference is 1,000 .

Researcher: Why didn't you choose the pairs of 1,200 \& 300?

Subject 2: It's also possible, we just reverse it; the former one is added and the latter is subtracted.

Researcher: Why should the price of 1,300 be subtracted and the price of 200 is added? Why didn't you subtract both prices?

Subject 2: To make it balance so that the total price remains 1,500.

Researcher: Why didn't you add and subtract15-by-15?

Subject 2: No, I tried 20-by-20 but it does not fit, then with 10-by-10, it's just right.

Researcher: Oh, I see, what are T, $P, B$, and $S$ ?

Subject 2: T is for total, $P$ is for pencil, B is for the eraser, and $S$ is for the difference.

(Dialogue between researcher and Subject 2, 2018)

Subject 2 understood the core of the problem and produced the right answer by making a list strategy. He started from the price pairs of a pencil and an eraser 1,400 \& 100, 1,300 \& 200 and $1,200 \& 300$. Two price pairs $(1,300 \& 200)$ and $(1,200 \& 300)$ gave a difference of $1,100 \& 900$. The numbers of $1,100 \& 900$ hinted at Subject 2 that the answer to the problem given is around this value, which is 1,000 . Furthermore, the answer of 250 was obtained by cognitive simulation which is a characteristic of system 2 (EVANS, 2012; PENNYCOOK, 2018). He added 10-by-10 to 200 to reach 250 and subtracts 10 -by-10 to 1,300 to reach 1,250 .

Stage 2 intervention indicates that it activates system 2, because the algorithm is detailed, the process is controlled and serial (BABAI; SHALEV; STAVY, 2015; BORODIN, 2016). The description of Subject 2's mental processes during problem-solving with the researcher's intervention occurs in the following 4 stages.

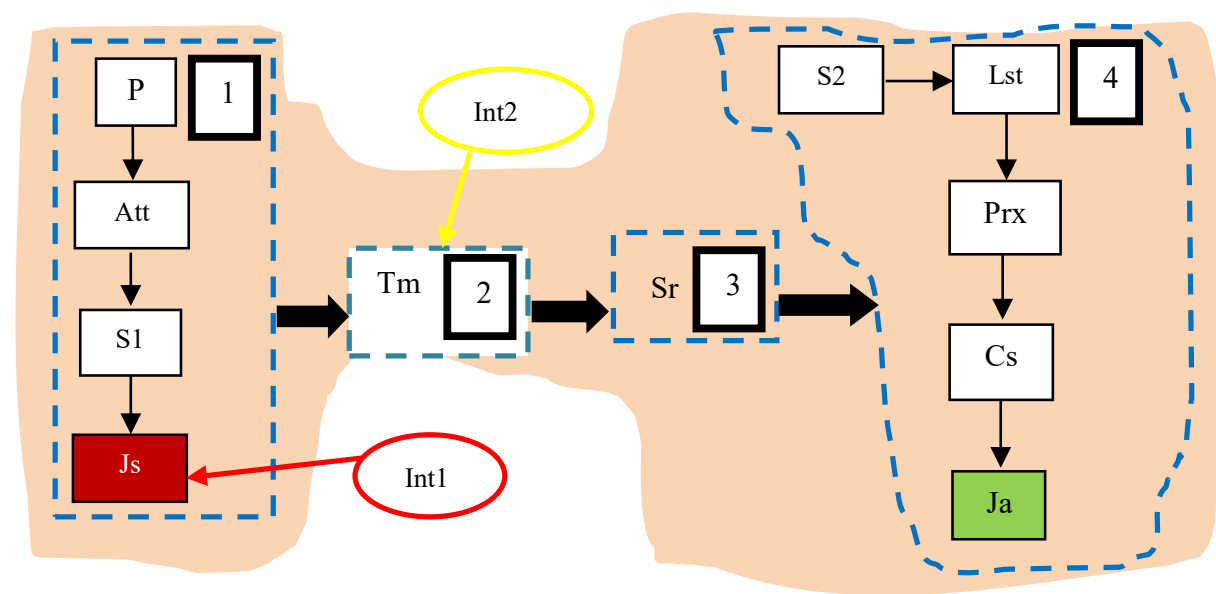

Figure 9-Subject 2's mental scheme Source: Researcher' data (2018)

The following is the description of Subject 2's mental scheme above.

\begin{tabular}{|c|c|}
\hline Code & Meaning \\
\hline $\mathrm{P}$ & Price problem \\
\hline Att & Encouraged to pay attention to IDR 1,000 and IDR 1,500 \\
\hline $\mathrm{s} 1$ & System 1 is active \\
\hline
\end{tabular}




\begin{tabular}{|c|c|}
\hline JS & The incorrect answer is 500 \\
\hline Tm & $\begin{array}{c}\text { Does not aware that the answer is incorrect and does not evaluate the } \\
\text { answer }\end{array}$ \\
\hline Int 1 & Stage 1 intervention \\
\hline Int 2 & Stage 2 intervention \\
\hline Sr & Realizing that the answer is incorrect \\
\hline S2 & System 2 is active \\
\hline Lst & Making a list \\
\hline Prx & Find the closest value \\
\hline Cs & Cognitive simulation \\
\hline Ja & The correct answer is 250 \\
\hline
\end{tabular}

Frame 3 - The description of Subject 2's mental scheme

Source: Researcher' data (2018)

\subsection{Intervention Stage 1: The case of Subject 3 (Modeling)}

Subject 3 gave her initial answer of 500 with an implicit process. She had similar experiences as Subject 1 and Subject 2. The following is Subject 3's written answer.

1500
1000
0500 $\Rightarrow 500$

Figure 10 - Subject 3's initial answer

Source: Researcher' data (2018)

Then the researcher gave stage 1 intervention as follows.

Researcher: Are you sure of your answer?

Subject 3: Sure, sir.

Researcher: Really?

Subject 3: Wait, sir, hmmm it seems incorrect. I will try again for a while.

(Dialogue between researcher and Subject 3, 2018)

Subject 3 realized that her answer was incorrect. After 15 minutes from the dialogue above, she stated that the correct answer was 250 . The following was the written answer by Subject 3 .

$$
\begin{aligned}
p_{h}+(p h+1000) & =1500 \text { Step } 1 \\
2 p h+1000 & =1500 \text { Step } 2 \\
2 p h & =1500-1000 \text { Step } 3 \\
2 p h: 2 & =500: 2 \text { Step } 4 \\
\text { ph } & =250 \text { Step } 5
\end{aligned}
$$

Figure 11 - Subject 3's algorithm

Source: Researcher' data (2018)

The above algorithm is detailed, which indicates the involvement of system 2. Subject 3 solved the problem by making a mathematical model. Next, the researcher asked Subject 3's explanation regarding her answer. 
Researcher: What is ph?

Subject 3: Eraser, sir.

Researcher: $P h+(P h+1,000)=1500$, what does it mean?

Subject 3: The price of one eraser and the price of one pencil is 1,500

Researcher: What is $(P h+1,000)$ ?

Subject 3: That's the price of one pencil, it is 1,000 more expensive, right?

(Dialogue between researcher and Subject 3, 2018)

Subject 3 gave the initials $P h$ for the price of one eraser, and the price of one pencil is $P h+1,000$ and made a mathematical model of $P h+(P h+1,000)=1,500$. Then, the researcher asked Subject 3 to ensure that system 2 was active during the process of completing the mathematical model.

Researcher: Why did you write $2 P h=1,500-1,000$ ? Then there is number 1,000 on the left side?

Subject 3: I moved it to the right sir, but the sign became (-)

Researcher: Is that the method?

Subject 3: Yeah, it's supposed to be that method.

Researcher: What if each side is subtracted by 1,000?

Subject 3: Indeed, the origin was it, but I already knew it, so that I shortened the steps.

Researcher: Ok, then $2 P h \div 2=500 \div 2$, what does it mean?

Subject 3: I divided it by 2, sir. So, I could find the price of one eraser.

Researcher: Why didn't you divide the right side by 5?

Subject 3: No, sir, the denominator must be the same.

Researcher: Why should it be?

Subject 3: I was taught that method, sir.

(Dialogue between researcher and Subject 3, 2018)

The dialogue above ensures that system 2 is involved in Subject 3's mental activity, which is characterized by cognitive decoupling, which is the part of the problem structure done mentally (EVANS, 2012). She broke down the problem structure into three components, namely the price of one eraser by $p h$, the price of one pencil by $p h+1,000$, and the total price of 1,500 . Then, she synthesized the three components to create a mathematical model $p h+p h+1,000=$ 1,500 .

The mental process when completing the mathematical model is not only system 2 (S2), but it also indicates the involvement of system 1 (S1). System 1 produces a response represented by $2 P h=1,500-1,000$, because Subject 3, automatically and confidently, referred her steps on the results of her learning experience, as she mentiones, "Indeed, it was the origin, but I already knew it, so that I shortened the step. Referring to action based on the results of learning experiences is the characteristic of system 1 (PARSONS, 2008; THOMPSON; JOHNSON, 2014). Subject 3's mental activity when completing the mathematical model above is described as follows. 


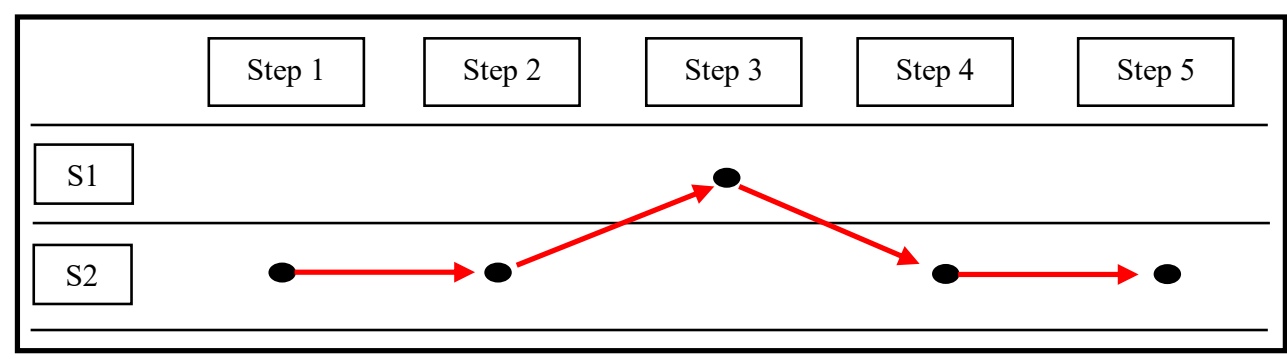

Figure 12 - The integration of system 1 and system 2 Source: Researcher' data (2018)

\subsection{Teacher Interventions Comparison on each subject}

Each research subject required teacher intervention to induce awareness in involving system 2, but in different stages. Subject 1 required intervention until stage 3, subject 2 required intervention until stage 2 , and subject 3 only required stage 1 intervention. For the three research subjects, the active moment of system 2 had the same characteristics, that is after the core problem was known.

Subject 1 recognized the gist of the problem but could not structure it. Therefore, the correct answer was generated by Subject 1 by guessing. Subject 3 recognized the core problem and could structure it. However, Subject 2 used ineffective problem-solving strategies to produce correct answers. Meanwhile, Subject $3 \mathrm{knew}$ the core problem, was able to structure it, and used effective problem-solving strategies to produce the correct answers. The core problem was ascertained by being preceded by feelings of doubt on the truth of the answers produced. The doubtful feeling arose because the teacher intervened. According to Darmawan, et al. (2020), the feeling of rightness is the key to raising student awareness in involving system 2.

\section{Discussion and conclusion}

The most significant activity for students in mathematics classroom is working on tasks, particularly problem-solving (AMARAL; CARREIRA, 2017; CUNHA; LAUDARES, 2017; JACINTO; CARREIRA, 2017). The consequence is that student reasoning must be adequate, but the reality that happens is the opposite. In the view of dual-process theory, the most common source of error in reasoning is the inactivity of system 2 to control the response of system 1 (BAGO; DE NEYS, 2017; LERON; HAZZAN, 2009). System 2 is not actively involved in controlling the response of system 1 because there is no student awareness referring to the need 
to involve system 2 (PENNYCOOK, 2018). That awareness arises if there are triggers (BAGO; DE NEYS, 2017; EVANS, 2012; HANDLEY, TRIPPAS, 2015; THOMPSON; JOHNSON, 2014). Triggers can appear in students' mental activity, one of which is when system 1 produces more than one type of response that competes in parallel (PENNYCOOK, 2018; DE NEYS, 2018). In this study, the salient information from a given problem activates system 1 , and a single response automatically was produced without competitors and was taken for granted uncritically. This finding is in accordance with the results of Babai, Shalev and Stavy (2015), De Neys (2015), Kahneman (2003), and Lem (2015). Meanwhile, teacher intervention is an activity that can be directly focused on influencing students when reasoning in problem-solving.

Furthermore, studies on teacher interventions are still rarely carried out and most previous studies only examined reasoning from the student's point of view, such as student difficulties, student motivation, student anxiety, and so on (GILBERTSON; WITT; LAFLEUR, 2007; VESS et al., 2018; WHEAR et al., 2013). Meanwhile, this study examined students' reasoning in solving problems from different points of view, namely from the teacher's point of view and the dual-process theory. Further, the results of this study show a significant impact on students' success in reasoning when solving problems that were initially dominated by system 1. This study examined teacher interventions using different methods and forms of interventions that have been applied in previous studies. In previous studies, teacher interventions given in the form of verbal warnings before students solve problems (BABAI; SHALEV; STAVY, 2015) and interventions in the form of picture provided with computer media (DEWOLF et al., 2014) proved less effective in inducing students' awareness in involving system 2 .

Teacher interventions conducted dialogically in this study proved to be effective in increasing the accuracy of student answers and this is in accordance with previous studies (GILBERTSON; WITT; LAFLEUR, 2007; VESS et al., 2018; WAGNER; AARON, 2017; WHEAR et al., 2013). Meanwhile, interventions conducted classically in the form of warnings before students solve problems such as those of Babai, Shalev and Stavy (2015) and Dewolf et al. (2014) proved ineffective, because students continued to experience difficulties. For this reason, the teacher interventions in this study were carried out dialogically in 3 stages individually according to the conditions of each student. In stage 1 intervention, the questions are about the students' beliefs on the answers, so that the students realize that the answers are incorrect and evaluate them. Stage 2 intervention is given if the students do not realize that the answer is incorrect and do not evaluate it after the intervention stage 1, by asking questions that are related to the content of the problem. The stage 3 intervention is given if the students have 
difficulty in structuring the problems.

Teacher's interventions with the above characteristics results in the emergence of 3 different types of students' responses to produce the correct answer, namely guessing, making a list, and modeling. The students who produce the correct answer by guessing need intervention until stage 3 because, after the intervention stage 1, the students think that they have finished, leaving the answer sheet without evaluating the answer. Therefore, the teacher increased intervention to stage 2 . Stage 3 intervention was done because students still did not know the core of the problem even though they realized that the answer was incorrect, which is indicated by reading the problem text repeatedly and talking to themselves. The students who produce the correct answer by making a list need the intervention until stage 2 because after the stage lintervention, they did not realize that the answer is incorrect, and they think that they have finished. The students who produce the right answer by modeling only required stage 1 intervention 1 , because they can immediately realize that the answer is incorrect and evaluate it.

Based on the results of this study, what teachers need to consider before making interventions to induce students' awareness in involving system 2 are the content and method of interventions. The content of interventions must be based on knowledge on the material mastered by students. This will tend to make students know quickly the core of the problem so that problems can be structured, and correct answers can be produced (CAPRIOARA, 2015; GUVEN; OZUM, 2013; JACINTO, CARREIRA, 2017; SPINILLO et al., 2017). Meanwhile, the method of interventions is a way to provide interventions that can be done directly, indirectly, and/or both. The direct method can be done by having dialogue or asking questions related to the problem content, while the indirect method can be done by giving an analogy with a simpler similar problem.

Furthermore, in determining the method of interventions, teachers must also pay attention to the timing, quantity, and forms of interventions. Intervention timings can be chosen at the beginning, in the middle, or at the end of the problem-solving process. The quantity of the intervention can be done according to the students' condition, for example one intervention, two interventions, or three interventions. Meanwhile, the forms of interventions include visuals, verbal forms, or both. Visual forms can be in the forms of images, animations, etc. Verbal forms can be in the forms of questions, sound recordings, etc. Based on the arguments above, further studies examining teacher interventions to students in the view of dual-process theory are still open and will have a direct impact on mathematics learning. So, further studies can be done at a higher level or on different materials. 


\section{References}

AMARAL, N.; CARREIRA, S. Mathematical Creativity In The Solutions of Students Participating In A Problem-Solving Competition. Bolema, Rio Claro, v. 31, n. 59, p. 880-906, dec. 2017.

BABAI, R.; SHALEV, E.; STAVY, R. A Warning Intervention Improves Students' Ability To Overcome Intuitive Interference. ZDM Mathematics Education, Karlsruhe, v. 47, n. 5, p. 735-745, jan. 2015.

BAGO, B.; DE NEYS, W. Fast Logic ?: Examining The Time Course Assumption Of Dual Process Theory. Cognition, Paris, v. 158, p.90-109, jan. 2017.

BALTACI, S.; YILDIZ, A.; GÜVEN, B. Knowledge Types Used By Eighth Grade Gifted Students While Solving Problems. Bolema, Rio Claro, v. 28, n. 50, p.1032-1055, dec. 2014.

BELLINI-LEITE, S. C. Dual Process Theory: Systems, Types, Minds, Modes, Kinds Or Metaphors? A Critical Review. Review of Philosophy and Psychology, Heidelberg, v. 9, n. 2, p. 213-225, jun. 2018.

BORODIN, A. The Need For An Application Of Dual-Process Theory To Mathematics Education. Cambridge Open-Review Educational Research E-Journal, Cambridge, v. 3, p. 1-31, sep. 2016.

CĂPRIOARĂ, D. Problem Solving - Purpose And Means Of Learning Mathematics In School. Social And Behavioral Sciences, Amsterdam, v. 191, p. 1859 - 1864, jun. 2015.

CUNHA, C. L.; LAUDARES, J. B. Problem Solving In Financial Mathematics For The Treatment Of Financial Education Matters In High School. Bolema, Rio Claro, v. 31, n. 58, p. 659-678, aug. 2017.

DARMAWAN, P.; PURWANTO, P.; PARTA, I. N.; SUSISWO. The Levels of Students' Feeling of Rightness (FOR) in Solving Polygon Perimeter Problems. International Journal of Instruction, Eskişehir, v. 13, n. 2, p. 549-566. apr. 2020.

DE NEYS, W. Heuristic Bias And Conflilct Detection During Thinking. In: ROSS, B. H. $1^{\text {st }}$ ed. The Psychology Of Learning And Motivation. Amsterdam: Elsevier Ltd., 2015. p. 1-32.

DE NEYS, W. Dual Process Theory 2.0. New York: Routledge, 2018.

DEWOLF, T.; DOOREN, W. V.; CIMEN, E. E.; VERSCHAFFEL, L. The Impact Of Illustrations And Warnings On Solving Mathematical Word Problems Realistically. The Journal Of Experimental Education, Milton, v. 82, n.1, p.103-120, jan. 2014.

DOOREN, W. V.; BOCK, D.; DEPAEPE, F.; JANSSENS, D.; VERSCHAFFEL, L. The Illusion Of Linearity: Expanding The Evidence Towards Probabilistic Reasoning. Educational Studies in Mathematics, Heidelberg, v. 53, n. 2, p. 113-138, jul. 2003.

DURNING, S. J.; DONG, T.; ARTINO, A. R.; SCHUWIRTH, L. Dual Processing. Perspectives on Medical Education, Heidelberg, v. 4, n. 4, p. 168-175, aug. 2015.

EVANS, J. S. B. T. Spot The Difference: Distinguishing Between Two Kinds Of Processing. Mind \& Society, Amsterdam, v. 11, n. 1, p. 121-131, jun. 2012.

EVANS, J. S. B. T. Dual Process Theory Perspectives, and problems. In: DE NEYS, W. $1^{\text {st }}$ ed. Dual Process Theory 2.0. New York: Routledge, 2018. p. 137-155.

FISCHBEIN, E. Intuitions And Schemata In Mathematical Reasoning. Educational Studies In Mathematics, Heidelberg, v. 38, n. 1-3, p. 11-50, mar. 1999. 
FU, Q.; DIENES, Z.; FU, X. The distinction between intuition and guessing in the SRT taskgeneration: A reply to Norman and Price. Consciousness and Cognition, Amsterdam, v. 19, n. 1, p. 478-480. 2010.

GILBERTSON, D.; WITT, J. C.; LAFLEUR, L. Supporting Teacher Use Of Interventions: Effects Of Response Dependent Performance Feedback On Teacher Implementation Of A Math Intervention. Journal Of Behavioral Education, New York, v. 16, p. 311-326, 2007.

GUVEN, B.; OZUM, B. Factors Influencing Mathematical Problem-Solving Achievement Of Seventh Grade Turkish Students. Learning And Individual Differences, Amsterdam, v. 23, p. 131-137, feb. 2013.

GREEN, D. R. survey of probabilistic concepts in 3000 students aged 11-16 years. In: GREY; HOLMES; BARNETT; CONSTABLE. Proceedings of the First International

Conference on Teaching Statistics. ${ }^{\text {st }}$ ed. Sheffield: Teaching Statistics Trust, 1983. p. 766-783.

HANDLEY, S. J.; TRIPPAS, D. Dual Processes And The Interplay Between Knowledge And Structure: A New Parallel Processing Model. In: ROSS, B. H. The Psychology Of Learning And Motivation. $1^{\text {st }}$ ed. Amsterdam: Elsevier Ltd., 2015. p. 33-58.

IMBIR, K. K. New Ideas In Psychology From Heart To Mind And Back Again. A Duality Of Emotion Overview On Emotion-Cognition Interactions. New Ideas In Psychology, Amsterdam, v. 43, p. 39 49, dec. 2016.

JACINTO, H.; CARREIRA, S. Different Ways Of Using Geogebra In Mathematical Problem-Solving Beyond The Classroom: Evidences Of Techno-Mathematical Fluency. Bolema, Rio Claro, v. 31, n. 57 , p. 266-288, apr. 2017.

KAHNEMAN, D. Maps Of Bounded Rationality: A Perspective On Intuitive Judgment. In: Nobel Prize lecture, $1^{\text {st }}$ ed, Stockholm: Nobel Media AB, 2003. p. 449-489.

LAMY, D.; LEBER, A.; EGETH, H. E. Effects Of Task Relevance And Stimulus-Driven Salience In Feature-Search Mode. Journal Of Experimental Psychology: Human Perception And Performance, Washington, v. 30, n. 6, p. 1019-031, 2004.

LEM, S. The Intuitiveness Of The Law Of Large Numbers. Zdm Mathematics Education, Karlsruhe, v. 47, n. 5 , p. $783-792$, sep. 2015.

LERON, U.; HAZZAN, O. Intuitive Vs Analytical Thinking: Four Perspectives. Educational Studies In Mathematics, Heidelberg, v. 71, n. 3, p. 263-278, jul. 2009.

LLERAS, A.; VON MÜHLENEN, A. Spatial Context And Top-Down Strategies In Visual Search. Spatial Vision, Leiden, v. 17, n. 4, p. 465-482, sep. 2004.

MARTIN, J. W.; SLOMAN, S. A. Refining The Dual-System Theory Of Choice. Journal of Consumer Psychology, Amsterdam, v. 23, n. 4, p. 552-555, oct. 2013.

MIHAELA, F.; VOICA, C. Between Perception And Intuition: Learning About Infinity. Journal Of Mathematical Behavior, Amsterdam, v. 27, n. 3, p. 188-205, 2008.

MULLIS, I. V. S.; MARTIN, M. O.; FOY, P.; ARORA, A.Timss 2011 International Results In Mathematics. Chestnut Hill: Timss \& Pirls International Study Center, 2012.

NCTM. Principles And Standards For School Mathematics. Reston: The National Council of 
Teachers, 2000.

OECD. Pisa 2015 Results In Focus. Paris: Oecd, 2018.

PARSONS, C. Mathematical Thought And Its Objects. New York: Cambridge University Press, 2008.

PENNYCOOK, G. A perspective on the theoretical foundation of dual process models. In: DE NEYS, W. Dual Process Theory 2.0. $1^{\text {st }}$ ed. New York: Routledge, 2018. p. 5-27.

SOUSA, C.; MENDES, F. Learning To Solve Problems In The $2^{\text {nd }}$ Grade Of Elementary School. Bolema, Rio Claro, v. 31, n. 2, p. 243-265, apr. 2017.

SPINILLO, A. G.; LAUTERT, S. L.; BORBA, R. E. de S. R.; DOS SANTOS, E. M.; DA SILVA, J. F. G. The Posing Of Mathematical Problems Involving Multiplicative Structures By Elementary School Teachers. Bolema, Rio Claro, v. 31, n. 59, p. 928-946, dec. 2017.

STAVY, R.; TIROSH, D. How Students (Mis-)Understand Science And Mathematics: Intuitive Rules. New York: Teachers College Press, 2000.

TAMBYCHIK, T.; SUBAHAN, T.; MEERAH, M. Students' Difficulties In Mathematics ProblemSolving: What Do They Say? Procedia - Social And Behavioral Sciences, Amsterdam, v. 8, n. 5, p. 142-151, 2010.

THOMPSON, V. A.; JOHNSON, S. C. Conflict, Metacognition, And Analytic Thinking. Thinking \& Reasoning, London, v. 20, n. 2, p. 37-41, sep. 2014.

VESS, S. F.; BEGENY, J. C.; NORWalk, K. E.; ANKNEY, R. N. Reading Fluency Interventions With Middle School Students: A Comparison Of The Helps Program And A Teacher-Directed Evidence-

Based Intervention. Journal Of Applied School Psychology, Thames, Oxfordshire, v. 34, n.2, p.1-22, 2018.

WAGNER, D. L.; AARON, M. C. Comparing Brief Experimental Analysis And Teacher Judgment For Selecting Early Reading Interventions. Journal Of Behavioral Education, New York, v. 26, n. 4, p. 348-370,2017.

WHEAR, R.; THOMPSON-COON, J.; BODDY, K.; FORD, T. The Effect Of Teacher-Led Interventions On Social And Emotional Behaviour In Primary School Children : A Systematic Review. British Educational Research Journal, Thames, Oxfordshire,v. 39, n. 2, p. 383-420, 2013.

ZINK, C. F.; PAGNONI, G.; MARTIN-SKURSKI, M. E.; CHAPPELOW, J. C.; BERNS, G. S. Human Striatal Responses To Monetary Reward Depend On Saliency. Neuron, Amsterdam, v. 42, n. 3, p. 509-517, 2004.

Submetido em 04 de Janeiro de 2020. Aprovado em 29 de Dezembro de 2020. 